\title{
STRUCTURE, COMPOSITION AND CONSERVATION OF BIRDS IN MANGALAVANAM MANGROVES, COCHIN, KERALA
}

\author{
E.A. Jayson \\ Division of Wildlife Biology, Kerala Forest Research Institute, Peechi, Kerala 680653, India. \\ Email:jayson@kfri.org
}

\begin{abstract}
Birds of Mangalavanam mangroves were studied from May 1998 to May 1999, based on observational methods. Forty-one species of birds were recorded representing 25 families. The most common bird species found at Mangalavanam were Little Cormorant (Phalacrocorax niger) and Black-crowned Night Heron (Nycticorax nycticorax). Highest species richness of birds was found in the months of May and July (18 species). Nesting of Little Cormorant and Black-crowned Night Heron was observed from February to July. Though the area is an ideal roosting site for Little Cormorant and Black-crowned Night Heron, observations during the 1998 and 1999 monsoons revealed high mortalities. House Crow was the main predator of the eggs and nestlings of other bird species. The major factors, which are detrimental to the ecosystem, are 1. Proposal to lease part of the land to a Trust, 2. Parking of oil tankers on the Salim Ali road, 3. Dumping of waste in the lake, 4. Air pollution due to the unloading of cement, 5. Encroachment of puramboke land on the eastern side, 6 . Uncontrolled growth of weeds in the lake. Recommendations for better management of the Mangalavanam mangroves have been provided.
\end{abstract}

\section{Keywords}

Mangalavanam mangroves, birds, inventory, conservation action, Kerala, Little Cormorant, Night Heron

\section{Introduction}

Mangrove is a complex ecosystem consisting of examples of plants of unrelated species converged in a similar habitat. The vegetation consists of evergreen trees and shrubs belonging to several unrelated families and share similar habitat and similar physiognomy. Mangroves occur in two formations viz. western formations consisting of the coasts of America, the West Indies and West Africa, and eastern formation along the coasts of India, East Africa, Malay and so on. In Kerala, mangroves are distributed in Keeryad Island, northern part of Kochi Port and Research Farm at Puthuvypu, Mahe to Dharmadam coastal belt, Mallikkad, Ashram, Pathiramanal, Mangalavanam and in several other bits (Basha, 1991). Mangrove area in Kerala is estimated to be about $17 \mathrm{~km}^{2}$ in 1992, of these 36 per cent are in degraded/ degrading condition (Basha, 1992). This is in comparison to the $700 \mathrm{~km}^{2}$ of mangroves, which existed in Kerala earlier (Ramachandran et al., 1985). The development of timber industry (mainly plywood industry), alternative land use and the establishment of fishing ports were the major reasons for the

Received 2 December 2000

Accepted 31 March 2001 degradation of the mangroves in Kerala.

Mangrove vegetation is important because a variety of marine organisms and fresh water forms depend on mangroves for feeding and as nursery grounds. According to a study by Snedaker (1978), 90 per cent of marine fish pass some stages of their life cycle in mangrove habitats. Mangroves serve the birds in different ways. Herons, storks, raptors and owls use them as nesting sites. Wintering palaeartic waders use them as roosting sites after feeding in the tidal mud flats. There were many attempts to study this complex ecosystem. Basha (1992) assessed the status and gave information on the potential mangrove areas in Kerala. Certain amount of research has been done on the vegetation and mapping aspects of mangroves in Kerala (Basha, 1991). Similarly, some studies are also available on the fishery potential of mangroves in the State (Purushan, 1989).

Ramachandran et al. (1985) attempted a study on the mapping, inventory and some environmental aspects of mangrove ecosystems in the State. Fifty-two species of fishes are known to occur in Kerala in association with the mangroves. Many 
authors have reported on the avifauna of mangroves of other countries (Cawkell, 1964; Field, 1968; French, 1966; Haverschmidt, 1965; Nisbet, 1968). A number of studies have been made on the birds of mangroves of India. Samant (1985) listed 121 species of birds occurring in the mangroves around Ratnagiri, Maharashtra. Kurup (1996) reported several species of birds occurring in the mangrove patches all along the Kerala coast. Based on available information, 76 species of birds are known to occur in association with the mangroves of Kerala. NEST (1993) published a list of birds found at Kumarakam. Mohandas et al. (1994) reported 57 species of birds occurring in the Asramam mangroves of Kollam. Objectives of the study were to document the structure and composition of bird fauna of the Mangalavanam mangrove and to document the threats to the ecosystem.

\section{Study area}

Mangalavanam is situated in the Ernakulam District of Kerala State $\left(90^{\circ} 59^{\prime} \mathrm{N}\right.$ and $\left.76^{\circ} 11^{\prime} \mathrm{E}\right)$. The study area is in Ernakulam City and the total extent is $8.44 \mathrm{ha}$. The northern and eastern portion of the area is bordered by Bharath Petroleum Company, South by Ernakulam Railway goods station, West by Salim Ali road and Central Marine Fisheries Research Institute. The ownership of the land is with various government agencies. Mangalavanam is a small mangrove area comprising of a shallow tidal lake in the centre with its edges covered with thick mangrove vegetation (Fig. 1). This water body is connected with backwaters by a canal. In the middle of the lake, there is a small island with mangrove growth. Mangalavanam gained importance because of the mangrove vegetation and also due to the congregation of communally breeding birds. Apart from these, it is considered a 'green lung' of Ernakulam City, which is polluted by many industries and motor vehicles. A timber yard was located in the area in the yester years, exporting timber to various countries. At present, no such activity is being carried out. The guesthouse was renovated in the year 1986 and regular staff was appointed to protect the birds.

There are two distinct seasons in the study area. The monsoon starting from end of May up to middle of November and the dry summer season from December to the first half of May. There is no clear-marked winter. Rainfall varies from $4 \mathrm{~mm}$ in March to $676 \mathrm{~mm}$ in June. There was not much variation in temperature. Vegetation of the area is dominated by mangrove species. Prominent species among them are Avicennia marina, Rhizophora mucronata and Acanthus ilicifolius. Exotic species like Eucalyptus was also planted in the area in previous years. Other planted species is teak. It is reported that 17 true mangrove species and 23 semimangrove species occur in Kerala (Unni \& Kumar, 1997).

\section{Figure 1. Map showing the location of Mangalavanam in Ernakulam City}

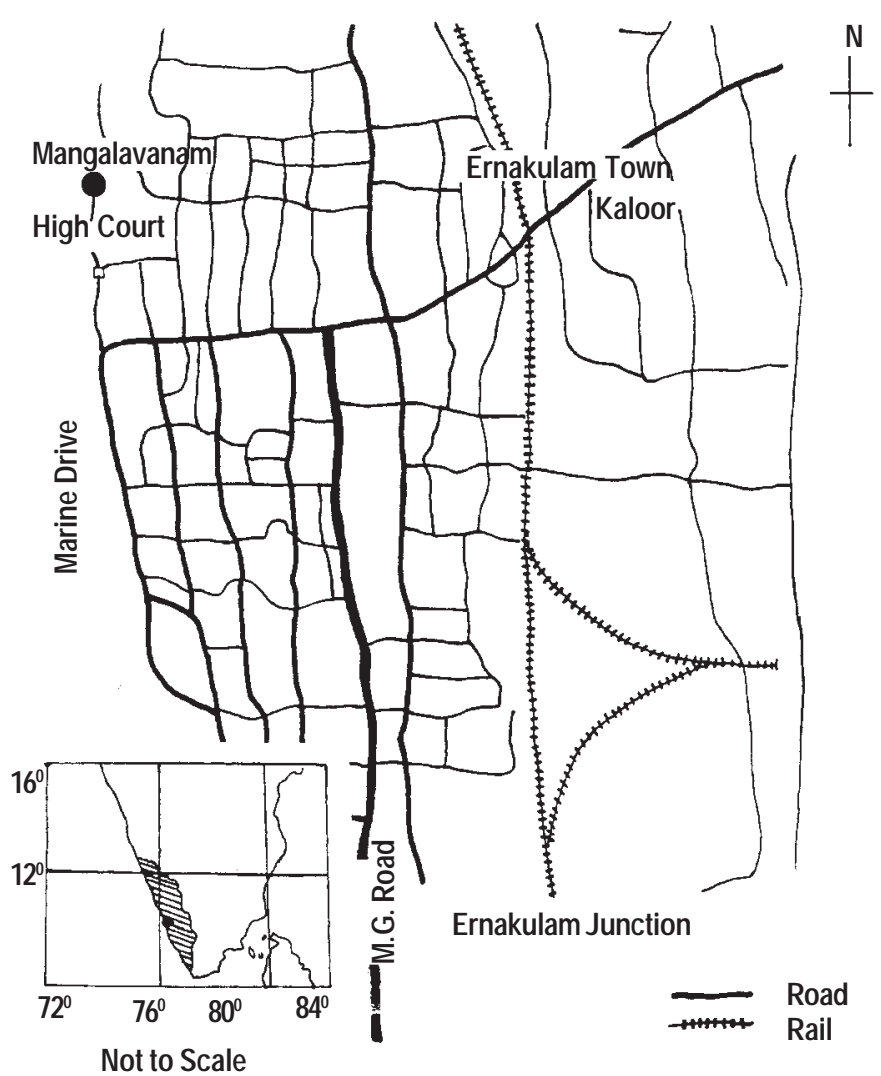

\section{Methods}

\section{Composition and occurrence of birds}

Composition and occurrence of birds in the area were recorded from field observations. The number of species recorded is considered as species richness. The method of total count was employed to census the birds in the area. This was carried out by dividing the area into three plots. First plot was near the Rest House inside the compound wall, the second one outside the compound wall and the last one on the islands. Three samples were taken in each month and no systematic data were collected on nocturnal birds. Species richness and composition of birds were computed from the census data and from the field observations. The information on the occurrence of birds in each month obtained from the census was used for seasonality analysis. Mean data obtained from the study period was used for this. Species richness, occurrence and seasonal fluctuations in the populations of Little Cormorant and Black-crowned Night Heron were studied in detail 
Table 1. Species of birds recorded at Mangalavanam in different months.

\begin{tabular}{|c|c|c|c|c|c|c|c|c|c|c|c|c|c|}
\hline Common name & Scientific name & $\mathbf{J}$ & $F$ & M & A & M & $\mathrm{J}$ & J & A & $\mathrm{S}$ & 0 & $\mathrm{~N}$ & D \\
\hline \multicolumn{14}{|l|}{ Phalacrocoracidae } \\
\hline Large Cormorant & Phalacrocorax carbo & - & - & - & $\mathrm{R}$ & $\mathrm{R}$ & - & - & - & - & - & - & - \\
\hline Little Cormorant & Phalacrocorax niger & $\mathrm{R}$ & $\mathrm{R}$ & $\mathrm{R}$ & $\mathrm{R}$ & $\mathrm{R}$ & $\mathrm{R}$ & $\mathrm{R}$ & $\mathrm{R}$ & $\mathrm{R}$ & $\mathrm{R}$ & $\mathrm{R}$ & $\mathrm{R}$ \\
\hline \multicolumn{14}{|l|}{ Anhingidae } \\
\hline Indian Darter & Anhinga melanogaster & - & - & - & - & $\mathrm{R}$ & - & $\mathrm{R}$ & - & - & - & $\mathrm{R}$ & $\mathrm{R}$ \\
\hline \multicolumn{14}{|l|}{ Ardeidae } \\
\hline Purple Heron & Ardea purpurea & - & - & - & - & $\mathrm{R}$ & - & $\mathrm{R}$ & - & - & - & - & - \\
\hline Indian Pond-Heron & Ardeola grayii & - & - & $\mathrm{R}$ & - & - & - & $\mathrm{R}$ & - & - & - & - & - \\
\hline Cattle Egret & Bubulcus ibis & $\mathrm{R}$ & & $\mathrm{R}$ & $\mathrm{R}$ & & - & - & - & - & - & - & $\mathrm{R}$ \\
\hline Great Egret & Casmerodius alba & $\mathrm{R}$ & $\mathrm{R}$ & $\mathrm{R}$ & $\mathrm{R}$ & & - & $\mathrm{R}$ & - & - & - & - & $\mathrm{R}$ \\
\hline IntermediateEgret & Mesophoyx intermedia & - & - & - & $\mathrm{R}$ & $\mathrm{R}$ & $\mathrm{R}$ & - & - & - & - & - & - \\
\hline Little Egret & Egretta garzetta & $\mathrm{R}$ & $\mathrm{R}$ & $\mathrm{R}$ & $\mathrm{R}$ & $\mathrm{R}$ & - & - & - & - & - & - & $\mathrm{R}$ \\
\hline Black-crowned Night-Heron & Nycticorax nycticorax & $\mathrm{R}$ & $\mathrm{R}$ & $\mathrm{R}$ & $\mathrm{R}$ & $\mathrm{R}$ & $\mathrm{R}$ & $\mathrm{R}$ & $\mathrm{R}$ & $\mathrm{R}$ & $\mathrm{R}$ & $\mathrm{R}$ & $\mathrm{R}$ \\
\hline \multicolumn{14}{|l|}{ Accipitridae } \\
\hline Black Kite & Milvus migrans & - & - & - & - & - & - & - & - & - & - & $\mathrm{R}$ & - \\
\hline \multicolumn{14}{|l|}{ Rallidae } \\
\hline White-breasted Waterhen & Amaurornis phoenicurus & $\mathrm{R}$ & - & - & - & - & - & $\mathrm{R}$ & - & - & - & - & - \\
\hline \multicolumn{14}{|l|}{ Charadriidae } \\
\hline Yellow-wattled Lapwing & Vanellus malabaricus & - & - & $\mathrm{R}$ & - & - & - & - & - & - & - & - & - \\
\hline \multicolumn{14}{|l|}{ Columbidae } \\
\hline Rock Pigeon & Columba livia & $\mathrm{R}$ & $\mathrm{R}$ & $\mathrm{R}$ & $\mathrm{R}$ & $\mathrm{R}$ & - & $\mathrm{R}$ & - & - & - & - & $\mathrm{R}$ \\
\hline \multicolumn{14}{|l|}{ Psittacidae } \\
\hline Plum-headed Parakeet & Psittacula cyanocephala & - & $\mathrm{R}$ & - & - & - & - & - & - & - & - & - & $\mathrm{R}$ \\
\hline \multicolumn{14}{|l|}{ Cuculidae } \\
\hline Asian Koel & Eudynamys scolopacea & $\mathrm{R}$ & $\mathrm{R}$ & $\mathrm{R}$ & $\mathrm{R}$ & $\mathrm{R}$ & - & $\mathrm{R}$ & - & - & - & $\mathrm{R}$ & - \\
\hline \multicolumn{14}{|l|}{ Centropodidae } \\
\hline Greater Coucal & Centropus sinensis & $\mathrm{R}$ & $\mathrm{R}$ & - & $\mathrm{R}$ & - & - & $\mathrm{R}$ & - & - & - & - & - \\
\hline \multicolumn{14}{|l|}{ Apodidae } \\
\hline House Swift & Apus affinis & - & - & - & - & - & - & - & - & - & - & $\mathrm{R}$ & - \\
\hline \multicolumn{14}{|l|}{ Alcedinidae } \\
\hline Common Kingfisher & Alcedo atthis & $\mathrm{R}$ & $\mathrm{R}$ & - & - & - & - & $\mathrm{R}$ & - & - & - & - & - \\
\hline \multicolumn{14}{|l|}{ Cerylidae } \\
\hline Lesser Pied Kingfisher & Ceryle rudis & - & - & - & - & $\mathrm{R}$ & - & - & - & - & - & - & - \\
\hline \multicolumn{14}{|l|}{ Dacelonidae } \\
\hline Stork-billed Kingfisher & Halcyon capensis & - & - & - & - & $\mathrm{R}$ & - & - & - & - & - & - & - \\
\hline White-throated Kingfisher & Halcyon smyrnensis & $\mathrm{R}$ & $\mathrm{R}$ & - & $\mathrm{R}$ & $\mathrm{R}$ & - & $\mathrm{R}$ & - & - & - & - & $\mathrm{R}$ \\
\hline \multicolumn{14}{|l|}{ Meropidae } \\
\hline Green Bee-eater & Merops orientalis & - & - & - & - & - & - & - & - & - & - & $\mathrm{R}$ & - \\
\hline
\end{tabular}




\begin{tabular}{|c|c|c|c|c|c|c|c|c|c|c|c|c|c|}
\hline Common name & Scientific name & $\mathrm{J}$ & $F$ & M & A & $M$ & $\mathrm{~J}$ & $\mathrm{~J}$ & A & $\mathrm{S}$ & 0 & $\mathrm{~N}$ & D \\
\hline \multicolumn{14}{|l|}{ Megalaimudae } \\
\hline White-cheeked Barbet & Megalaima viridis & - & $\mathrm{R}$ & - & - & - & - & - & - & - & - & $\mathrm{R}$ & - \\
\hline \multicolumn{14}{|l|}{ Picidae } \\
\hline \multicolumn{14}{|l|}{ Black-rumped Flamebacked } \\
\hline Woodpecker & Dinopium benghalense & $\mathrm{R}$ & - & - & - & - & - & - & - & - & - & - & - \\
\hline \multicolumn{14}{|l|}{ Corvidae } \\
\hline Eurasian Golden Oriole & Oriolus oriolus & - & - & $\mathrm{R}$ & - & - & - & - & - & - & - & - & - \\
\hline Black Drongo & Dicrurus macrocercus & - & - & - & - & - & - & $\mathrm{R}$ & - & - & - & - & - \\
\hline Rufous Treepie & Dendrocitta vagabunda & - & - & - & - & - & - & - & - & & - & $\mathrm{R}$ & - \\
\hline House Crow & Corvus splendens & $\mathrm{R}$ & $\mathrm{R}$ & $\mathrm{R}$ & $\mathrm{R}$ & $\mathrm{R}$ & $\mathrm{R}$ & $\mathrm{R}$ & $\mathrm{R}$ & $\mathrm{R}$ & $\mathrm{R}$ & $\mathrm{R}$ & $\mathrm{R}$ \\
\hline Jungle Crow & Corvus macrorhynchos & - & - & - & - & - & - & - & - & - & - & $\mathrm{R}$ & - \\
\hline \multicolumn{14}{|l|}{ Muscicapidae } \\
\hline Oriental Magpie-Robin & Copsychus saularis & $\mathrm{R}$ & $\mathrm{R}$ & $\mathrm{R}$ & - & $\mathrm{R}$ & - & $\mathrm{R}$ & - & - & - & - & $\mathrm{R}$ \\
\hline \multicolumn{14}{|l|}{ Sylviidae } \\
\hline Pale-capped Babbler & Turdoides affinis & - & - & - & - & - & - & $\mathrm{R}$ & - & - & - & - & - \\
\hline Common Tailorbird & Orthotomus sutorius & - & - & - & - & - & - & - & - & - & - & - & - \\
\hline \multicolumn{14}{|l|}{ Sturnidae } \\
\hline Common Myna & Acridotheres tristis & - & $\mathrm{R}$ & - & - & $\mathrm{R}$ & - & $\mathrm{R}$ & - & - & - & - & - \\
\hline Jungle Myna & Acridotheres fuscus & - & $\mathrm{R}$ & - & - & - & - & - & - & - & - & - & - \\
\hline \multicolumn{14}{|l|}{ Irenidae } \\
\hline Jerdon's Leafbird & Chloropsis cochinchinensis & - & - & - & $\mathrm{R}$ & - & - & - & - & - & - & $\mathrm{R}$ & - \\
\hline \multicolumn{14}{|l|}{ Pycnonotidae } \\
\hline Red-whiskered Bulbul & Pycnonotus jocosus & - & - & - & - & - & - & - & - & - & - & $\mathrm{R}$ & - \\
\hline \multicolumn{14}{|l|}{ Mottacillidae } \\
\hline White Wagtail & Motacilla alba & - & - & - & - & $\mathrm{R}$ & - & - & - & - & - & - & - \\
\hline Large Pied Wagtail & Motacilla maderaspatensis & - & - & - & - & - & - & - & - & - & - & $\mathrm{R}$ & - \\
\hline House Sparrow & Passer domesticus & - & $\mathrm{R}$ & - & - & - & - & $\mathrm{R}$ & - & - & - & - & - \\
\hline \multicolumn{14}{|l|}{ Nectarinidae } \\
\hline Purple Sunbird & Nectarinia asiatica & $\mathrm{R}$ & - & - & - & - & - & $\mathrm{R}$ & - & - & - & - & $\mathrm{R}$ \\
\hline
\end{tabular}

R - Recorded 


\section{Results}

Mangalavanam is primarily a bird refuge. All other species of vertebrates are present in low numbers. The Indian Flying Fox (Pteropus giganteus), Painted Bat (Kerivoula picta), Threestriped Palm Squirrel (Funambulus palmarum), House Rat (Rattus rattus), Bandicoot-rat (Bandicota sp.) were recorded from the area. Considering this, the objective of the management should be to manage the birds found in the area in a better manner. In this study, maximum effort was made to understand the dynamics of the bird community.

\section{Composition and occurrence of birds}

Species composition of birds in an area is related to the type of vegetation, height above the sea level, availability of microhabitats and various other factors. Forty-one taxa of birds were recorded from the Mangalavanam mangroves. These species were from 25 families (Table 1). The common bird species found at Mangalavanam were Little Cormorant and Blackcrowned Night Heron. Passeriformes were maximum followed by Ciconiiformes and Pelecaniformes (Table 1). Only two species with local movements were recorded from the area, namely Eurasian Golden Oriole and Large Pied Wagtail. Except for Little Cormorant and Black-crowned Night Heron, other species were low in numbers.

Little Cormorant, Black-crowned Night Heron and House Crow were seen in all the months (Table 1). Large Cormorant was sighted only in May and June. The Darter was sighted during four months and egrets were seen during half the year. Other species recorded in more than four months were Asian Koel and Oriental Magpie-Robin. All other species were sighted only once or twice. Maximum species richness was seen in the month of May during summer and then in February (Table 2). Lowest was recorded in September, October and November. The area acquires the atmosphere of a bird sanctuary due to congregation of Little Cormorant and Black-crowned Night Heron in large numbers. Sighting of Black-crowned Night Heron during the day provide ample opportunity for the tourists to watch the birds during the day. In the evening, after the arrival of Little Cormorants, the whole area reverberates with the cacophony of birds. No migratory waders or shore birds were recorded during the study period. Most of the species seen in the area were aquatic feeders (16) followed by insectivorous species (14).

Table 2. Number of species of birds observed in different months at Mangalavanam.

\begin{tabular}{lllllllllllll}
\hline Months & $\mathbf{J}$ & $\mathrm{F}$ & $\mathbf{M}$ & $\mathbf{A}$ & $\mathbf{M}$ & $\mathrm{J}$ & $\mathrm{J}$ & $\mathbf{A}$ & $\mathbf{S}$ & $\mathbf{O}$ & $\mathrm{N}$ & $\mathbf{D}$ \\
\hline \# species & 15 & 17 & 13 & 13 & 18 & 4 & 18 & 3 & 3 & 3 & 13 & 13 \\
\hline
\end{tabular}

One Little Cormorant with white feathers all over the body was recorded from the area. The bird was seen on the island many times. Occurrence of Little Cormorant with white and brown feathers was reported earlier also (Ripley, 1962).

\section{Seasonal fluctuations}

Species richness and total number of birds varied in different months (Table 2). An increase in species richness is visible during summer. Highest number of species, i.e. 18 is recorded during the months of May and July. August, September and October showed lowest species richness.

\section{Mortality}

Mortality of nestlings of Little Cormorant and Black-crowned Night Heron was observed during the 1998 and 1999 monsoon (Table 3). During heavy rains, many nestlings fell down and succumbed to injuries. Hundred and ninety-nine nests of Little Cormorant and hundred and seven nests of Black-crowned Night Heron were recorded in the month of June.

\section{Predators}

House Crow was the main predator of the eggs and nestlings of other bird species at Mangalavanam. About 40 House Crows were found at Mangalavanam during the peak breeding period. They were sighted in the area, even when the nests were absent. House Crows usually perch on the tree branches where the nests are located and whenever a visitor approached the nests too closely, the parent birds will leave the nests out of fear. At this time, House Crows will snatch away either the eggs or nestlings. Apart from the House Crow, the Common Rat Snake (Ptyas mucosus) was a potential threat to the nestlings and eggs. Three-striped Palm Squirrels were seen near the nests but they were not seen feeding on eggs.

\section{Feeding}

Little Egret, Indian Pond-Heron and Cattle Egret utilised the lake for feeding. They waded through the shallow water during low tide and searched for prey. Little Cormorants were seen utilising the lake during high tide to feed on fish and other organisms by diving.

Table 3. Number of nestlings fell down from nests during the monsoon of 1998.

\begin{tabular}{lcl}
\hline Date & Nestling mortality & Species \\
\hline 02.vi.1998 & 16 & Little Cormorant \\
02.vi.1998 & 8 & Night Heron \\
17.vi.1998 & 2 & Little Cormorant \\
19.vi.1998 & 2 & Little Cormorant \\
20.vi.1998 & 1 & Little Cormorant \\
\hline
\end{tabular}




\section{Discussion}

Conservation of mangroves is urgently needed for maintaining the faunal diversity associated with it. Mangroves also help in protection of coasts against erosion and flooding. Mangalavanam is important due to many factors. The area is well protected from natural predators and not many similar communal roosting sites are available to birds in a crowded city like Ernakulam. This site is crucial to the city dwellers also because the area serves as greenery in the middle of the urban expanse. Apart from the much needed breeding and roosting site for birds, the rare and threatened mangrove vegetation is preserved here. For a small area like Mangalavanam, the occurrence of 41 taxa of birds representing 25 families is worth mentioning. Even though considered a wetland area, the attracts a large number of species from passerine group. Mangalavanam qualifies the criteria for declaring it as an International IBA (Important Bird Area) of the Birdlife International due to the presence of more than 1500 Little cormorant and the presence of more than 1000 Black-crowned Night Heron, which form one per cent of the total global population. Trans-continental migratory species were absent in the area. Migratory ducks and waders were conspicuous by their absence. The absence of migratory birds can be explained due to the non-availability of suitable habitats in the area. Shallow water spread was very low in extent, which is preferred by the migratory waders. As reported in a previous study (Jayson, 1994), maximum species richness was observed during the summer months.

Two common species found in the area are Little Cormorant and Black-crowned Night Heron. These two species are found all over Kerala and distributed throughout the subcontinent except parts of north-west, north-east and the Himalaya (Grimmett $e t$ al., 1998). Feeding guild analysis indicated that 16 species were aquatic feeders and 14 insectivorous. Carnivores were very few in number. During heavy rain, many nestlings fell down and were easy prey to the ground predators. Mortality of similar nature has been reported from Kokkare Bellur, near Bangalore also (Subaramanya \& Mani, 1996). Field studies revealed that there is a shortage of available space for building nests. There was heavy competition to acquire suitable nest sites. To provide additional nest sites, more mangrove saplings can be planted in the area. Possibility of providing artificial nest platforms also can be experimented in future studies. No suitable explanation for the non-breeding egrets could be propounded. As no residential houses are located in the vicinity, the roost is not a disturbance to human habitation. Apart from functioning as a breeding site, another important feature of the Mangalavanam is its role as a communal roosting site for Black-crowned Night Heron and Little Cormorant.

The factors, which usually influence the selection of sites for roosting, are proximity to the food source and water (Haneda et al., 1966) and isolation from human activity (Ross, 1973). Gadgil
(1971) suggested the hypothesis of protection against predators as the function of communal roosting. Protection from natural predators and increased feeding efficiency due to the proximity to the food source may be the two factors, which favour the Mangalavanam as a preferred roosting site for Little Cormorant and Black-crowned Night Heron. The six threats identified are detrimental to the ecosystem and grave in nature. If these threats are not ameliorated in future, the ecosystem will not improve. Future studies should concentrate on the roosting and breeding biology of Little Cormorant and Black-crowned Night Heron, predator pressure and availability of trees. Introduction of artificial nest platforms and protection of fallen nestlings using artificial pens also need investigations. Apart form these, rigorous and intensive surveys should be conducted in the surrounding areas to locate possible similar roosting and breeding sites.

\section{Conservation issues}

\section{Problems and recommendations}

People in the surrounding areas depend heavily on Mangalavanam for various resources. Fishery potential is exploited by the local people and crab hunting; using lines is a regular practice. Chicken waste is hooked on the lines and used as bait for hunting. Ten to 15 such lines were operated at a time and crabs were caught from the lake. Adverse factors, which have a deleterious effect on the existence of Mangalavanam mangroves, are discussed below.

\section{Visitors should not be allowed to go near the nesting trees}

When visitors go near the nesting trees, the parent birds leave the nest and waiting House Crows predate on the nestlings. Strict instructions should be given to prevent visitors from approaching the trees.

\section{Preferred tree species}

When protected area managers search for species of trees, which are beneficial to birds, fruit bearing and nectar providing species are generally recommended. However, at Mangalavanam as the birds mainly arrive for roosting and breeding, the question of providing fruits and nectar does not arise. Here the objective should be to provide trees, which may provide good shelter at night and strong platforms for building nests. Presently, most of the nests are placed on mangrove species. Considering this and the fact that the area is a mangrove, only mangrove species should be planted in future.

\section{Proposal to lease land from Mangalavanam}

There is a proposal to lease part of the land to a memorial trust, which will adversely affect the birds of Mangalavanam. Construction of a memorial trust (building) will result in loss of habitat and trees that are vital for roosting and nesting birds. Since the extent of Mangalavanam is already small, it is advisable not to divert any more land for other purposes. Alternative land 
can be allotted to the trust instead of the crucial area from the Mangalavanam mangroves.

\section{Parking of oil tankers in the Salim Ali Road}

At any given time, about 35 oil tankers can be seen parked on Salim Ali road, which runs parallel to the Mangalavanam. The drivers and cleaners of the tankers utilise Mangalavanam for toilet purposes, as no other facility is available. Two temporary teashops also function on the road, which is further blocking the smooth vehicular traffic and is a source of disturbance. Greater Cochin Development Authority has a proposal to shift the parking area from Salim Ali Road to the newly built road, which passes in front of the Central Marine Fisheries Research Institute. If this is implemented, the approach to the Mangalavanam will get a much-needed aesthetic uplift and the disturbance to the birds will be minimised.

\section{Dumping of waste in the lake}

The lake situated in the middle of the area is used for dumping the waste of the locality. Unwanted materials, both biodegradable and non-degradable are thrown in the lake. Apart from these, the hardened cement bags found in the railway wagons were also discarded into the lake. Polythene bags and floating waste materials also enter the water during high tide and get entangled among the weeds in the lake. Due to these activities, the lake is clogged. Conversion of the lake into terrestrial land will seriously affect the food availability of water birds. Efforts may be initiated to remove the waste materials from the lake and to clean the area. This should be carried out only during the months of November or December when breeding activity is low.

\section{Air pollution due to the unloading of cement bags}

On an average, 70 trucks operate in the railway goods yard at a given time. The cement dust produced from the unloading of cement is deposited on the vegetation of the area. This may lead to the death or retarded growth of plants and trees. Suitable action should be initiated to solve this problem, which is also a health issue to local residents.

\section{Encroachment of Puramboke land in the vicinity}

Encroachment of revenue land near the eastern portion of the area is a serious problem to the mangrove and its bird community. Land authorities should initiate required preventive measures against illegal encroachment.

\section{Improvement of lake}

Invasion of the lake by various weeds, particularly by Eichornia during the monsoon (June to January) is another disturbance to the mangrove community. When the waterfront is closed, due to the growth of weeds, the diving birds are deprived of the opportunity to feed in the lake. By December, the weed is completely dry, when, if the silt accumulated in the lake is removed, the fish fauna will flourish. This will help in providing adequate food to the young and juvenile birds. If sufficient food is available in the vicinity, the chances of survival of nestlings will be higher. As the lake is not deep, the fish fauna found in the lake is meager. During the study, only a few species of fish were collected from the lake and their abundance was found to be very low.

\section{Facilities for visitors}

Primary facilities for tourists are lacking in this area. Tourists visiting the area would like to know more about the details of the birds inhabiting the swamps. Except for the few photographs exhibited in the Guesthouse, no information is provided to the tourists. Authorities should take positive role in developing proper educational facilitites for tourists, thereby retaining the function of the mangrove.

\section{Acknowledgements}

The Kerala Forest and Wildlife Department gave financial assistance for the project. We are indebted to Dr. B.S. Corrie I.F.S., Conservator of Forests (SF and NSC), Ernakulam for his keen interest in the study. Dr. J.K. Sharma, Director, KFRI and Dr. P.S. Easa have given much advice during the study. Dr. R. Gnanaharan and an anonymous reviewer went through the draft critically and suggested many changes, which is acknowledged with gratitude. Mr. C. Sivaperuman and field staff of the Mangalavanam mangroves assisted the study in many ways.

\section{References}

Cawkell, E.M. (1964). The utilization of mangroves by African birds. Ibis 106: 251-253.

Basha, C. S. (1991). Distribution of mangroves in Kerala. Indian Forester 117:439-448.

Basha, C. S. (1992). Mangroves of Kerala - a fast disappearing asset. Indian Forester 118: 175-190.

Grimmett, R., C. Inskipp and T. Inskipp (1998). Birds of the Indian Subcontinent. Oxford University Press, New Delhi. 888 pp.

French, G.D. (1966). The utilization of mangroves by birds in Trinidad. Ibis 108: 423-424.

Field, G.D. (1968). Utilization of mangroves by birds on the Freetown Peninsula, Sierra Leone. Ibis 110:354-357.

Gadgil, M. (1971). The function of communal roosts. Relevance and mixed roosts. Ibis 114:531-533.

Haneda, K., V. Lida, T. Kagwa, T. Moti and S. Yamasingh (1966). Roosting flock area of crows in North Nagano prefecture. Japanese Journal of Ecology 16:213-215.

Haverschmidt, F. (1965). The utilization of mangroves by South American birds. Ibis 107:540-542.

Jayson, E.A. (1994). Synecological and behavioural studies on the forest birds of Kerala. Ph.D. Thesis, University of Calicut, 314 pp. (Unpublished).

Kurup, D.N. (1996). Ecology of the birds of Barathapuzha estuary and survey of the coastal wetlands of Kerala. Final report submitted to Kerala Forest Department, Trivandrum 59 pp.

Manakadan, R., J.C. Daniel, A.R. Rahmani, M. Inamdar and G. 
Ugra (1998). Standardized English common names of the birds of the Indian sub continent - a proposal. Buceros 3(2): 55 pp, BNHS, Mumbai. Mohandas, A., N. Ramanujan and P. Sreedevi (1994). The effect of man-made changes in the mangrove ecosystem at Asramam, Kollam. Proceedings of the $6^{\text {th }}$ Kerala Science Congress, Thiruvanathapuram, pp 55-57.

NEST (1993). Birds of Vembanad Lake: A survey Report, Nature Education Society, Trichur. 18 pp.

Nisbet, I.C.T. (1968). The utilization of mangroves by Malayan birds. Ibis 110: 348-352.

Purushan, B.S. (1989). Puduveypu- A potential brackish water fish seed resource. Fishing Chimes, February: 63-66.

Ramachandran, K.K., G. Balasubramanian, J. Kurian and J. Thomas (1985). The mangrove ecosystem of Kerala, Its mapping inventory and some environmental aspects. Interim Report, CESS, Trivandrum $47 \mathrm{pp}$.
Ripley, S.D. (1962). Unusual plumage of the Little Cormorant (Phalacrocorax niger (Vieillot)). Journal of the Bombay Natural History Society 59: 285-286.

Ross, P.K. (1973). Notes on wintering Great Cormorant in Nova Scotia. Canadian Field Naturalist 88: 493-494.

Samant, J. S. (1985). Avifauna of the mangroves around Ratnagiri, Maharashtra. In: The Mangroves, Proceedings of the National Symposium on Biology, Utilization and Conservation of Mangroves. pp. $456-466$.

Snedaker, S.C. (1978). Natural Resources. 13: 6-13. UNESCO, Paris. Subramanya, S. and K. Mani (1996). Saving the Spot-billed Pelican, a successful experiment. Hornbill 2: 2-6.

Unni, P.N. and M. Kumar (1997). Biodiversity in the mangrove vegetation of Kerala. Paper presented in the "Workshop on mangroves of Kerala" Science, Technology and Environment Department, Govt. of India. 